\title{
Lingkungan Belajar, Sikap Terhadap Profesi Guru terhadap Intensi Menjadi Guru (Studi pada Mahasiswa Fakultas Ekonomi Universitas Negeri Jakarta)
}

\author{
Ari Saptono \\ Fakultas Ekonomi, Universitas Negeri Jakarta \\ arisaptonoekop@yahoo.com \\ Suparno \\ Fakultas Ekonomi, Universitas Negeri Jakarta \\ suparno@unj.ac.id
}

\begin{abstract}
This study aims to determine how much direct influence of the school environment and the attitude of the teaching profession to the intention to become a teacher, Student Education at the Faculty of Economics UNJ 2015. The study was conducted by the method used is the ex post de facto with the correlational approach dngan analysis techniques lane (Path Analysis) in which the school environment directly affects the intention to become a teacher, the attitude of the teaching profession directly influence the learning outcomes of economics, as well as the school environment directly influence the attitude the teacher procession. The results showed that there is a direct influence between the variables studied based on the hypothesis. With the test model fit obtained in accordance with the hypothesis that the model empirical model of the same value by stating that the model can be accepted.
\end{abstract}

Keywords: Environmental Learning, Attitudes Toward Teaching profession intentionBecome a Teacher 


\section{PENDAHULUAN}

Pendidikan adalah bidang yang sangat penting bagi pembangunan suatu Negara. Peningkatan dan pengembangan Sumber Daya Manusia (SDM) serta teknologi dalam mempersiapkan generasi penerus suatu bangsa dilaksanakan melalui pembelajaran disekolah. Keberhasilan guru dalam mendidik sangat penting. Guru menentukan keberhasilan dalam pembelajaran siswa yang pada akhirnya akan mempengaruhi mutu pendidikan Nasional secara keseluruhan. Berbagai profesi menjadi pilihan bagi lulusan Sarjana Pendidikan, tetapi minat menjadi guru masih sangat rendah dibandingkan profesi lainnya sehingga masalah yang dikaji dalam penelitian ini adalah rendahnya intensi menjadi guru.

Kondisi pendidikan Indonesia saat ini dalam keadaan gawat darurat, hal tersebut disampaikan oleh Menteri Pendidikan dan Kebudayaan Anies Baswedan (Gabrillin, 2014) bahwa tren kinerja Indonesia pada pemetaan Program Penilaian Pelajar Internasional/ Program for International Student Assessment (PISA) yang bekerjasama dengan Organisasi untuk Kerjasama dan Pengembangan Ekonomi (OECD) menguji performa akademis anak - anak sekolah yang berusia 15 tahun, dari tahun 2000-2012 stagnan, 76 persen anak Indonesia masuk dalam kategori low achievers. Sementara anak yang mencapai level tertinggi hanya 0,3 persen. Minat membaca anak Indonesia juga sangat rendah hanya satu dari 1.000 orang Indonesia yang punya minat baca, atau 0,001 persen. Terdapat 75 persen sekolah Indonesia tidak memenuhi standar minimal pendidikan. Nilai uji kompetensi guru Indonesia hanya 44,5 dari standar yang diharapkan 70 persen dan Indonesia menduduki peringkat ke40 dari 42 negara pada pemetaan TIMSS bidang literasi sains. Peringkat 49 dari 50 negara pada pemetaan mutu pendidikan tinggi serta posisi ke-40 dari 40 negara pada pemetaan the learning curve

UU No 14/2005 tentang Guru dan Dosen memperbolehkan semua sarjana dari seluruh program studi untuk profesi guru karena dalam penerimaan calon guru yang lebih dipentingkan adalah kompetensi atas ilmu bukan kompetensi mendidik yang diperoleh dari pedagogi di lembaga kependidikan. Pada sisi lain kesejahteraan guru dan pemerataannya masih sangat sulit dicapai.

Kesejahteraan guru yang terasa saat ini adalah guru DKI sebagai pegawai pemda yang mendapatkan gaji mencapai 12 juta perbulan (Setiyadi, 2014)tetapi tidak seluruh kabupaten/kota menerapkan kebijakan yang sama. Guru honorer dan Sulitnya menjadi guru dengan status PNS juga membayangi lulusan yang berminat menjadi guru. Terdapat sekitar 500 guru honor SD dan SMP di Kabupaten Timor Tengah Selatan, Nusa Tenggara Timur, yang mendapat honor Rp 50.000-Rp 100.000 per bulan. Mereka kebanyakan mengajar di sekolah swasta. Panggilan mengabdi membuat mereka tetap bertahan (Ama Khayam, 2013).

Menjadi guru ternyata semakin sulit. Kemenristek Dikti (Supriyadi 2014) menyatakan bahwa mulai 2016 akan menyaring calon guru melalui dua filter. Tahapan pertama ialah setiap calon guru akan diwajibkan mengikuti SM3T 
(Sarjana Mendidik di daerah Terdepan, Terluar, Terpencil) dengan daerah khusus tujuan terbesar adalah Papua, selanjutnya setelah mereka mengabdi di daerah 3T maka mereka akan diasramakan di lembaga pendidik tenaga kependidikan (LPTK) selama satu tahun melalui program Pendidikan Profesi Guru (PPG). Setelah lulus SM3T dan PPG mereka akan digembleng kompetensi pribadi dan sosialnya untuk dapat menjadi guru profesional.

Perguruan Tinggi pendidikan sebagai pencetak guru sangat mempengaruhi pilihan mahasiswa lulusannya untuk memilih profesi sebagai guru. Pembelajaran konstruktivisme memberikan keleluasaan mahasiswa membangun pengetahuan dan pengalaman secara mandiri melalui lingkungan pembelajaran sehingga akan mempengaruhi minat menjadi guru. Dalam teory of planed behavior (Ajzen, 2005) menyatakan bahwa perilaku seseorang ditentukan oleh minatnya terhadap perilaku tersebut. Sedangkan minat seseorang terhadap perilaku (behavior intention) merupakan fungsi dari sikap seseorang terhadap perilaku (attitudes), Norma subyektif (subyektif norm) dan kontrol perilaku (perceived behavior control). Oleh karena itu TPB akan dijadikan sebagai prediktor mengukur intensi menjadi guru dalam penelitian ini. Lingkungan belajar, kecerdasan menghadapi masalah, dan efikasi diri seseorang akan menjadi sangat penting dalam melihat perilaku akhir seseorang dalam menentukan suatu pilihan termasuk intensi menjadi guru.
Lingkungan pembelajaran memberikan iklim yang kondusif dalam membentuk minat mahasiswa. Hasil pembelajaran yang baik dapat diperoleh apabila lingkungan pembelajaran mendukung dan terciptanya suasana akademik yang mendorong mahasiswa untuk berprestasi. Minat mahasiswa kependidikan akan terbentuk dengan lingkungan pembelajaran yang baik. Hal tersebut dapat terjadi karena menjadi seorang guru membutuhkan keterampilan dan kemampuan yang baik yang terbentuk melalui lingkungan pembelajaran.

Profesi guru adalah pilihan mulia yang dapat dijadikan sebagai lapangan pekerjaan. Melalui pembelajaran siswa mengalami perubahan pemikiran dan perilaku yang dibentuk oleh seorang guru. Kewajiban guru yang sangat besar terkadang belum sesuai dengan pendapatan yang diperoleh untuk dapat menyekolahkan anak anak mereka pada sekolah unggulan tempat guru mengajar.

Fakultas Ekonomi Universitas Negeri Jakarta (FE UNJ) meluluskan Sarjana Pendidikan (S.Pd) pada jenjang S1 dengan memberikan bekal proses perkuliahan yang baik. Penelusuran lulusan Fakultas Ekonomi dalam kegiatan penelitian tracer study pada tahun 2014 diperoleh data bahwa lulusan FE UNJ (Fauzi, 2014) memberikan data bahwa pilihan profesi menjadi guru dari

325 lulusan adalah 28 Orang atau 8,6\%, sedangkan yang menjadi Karyawan perusahaan adalah 284 Orang atau $87,4 \%$. Hal tersebut mengindikasikan masih rendahnya lulusan kependidikan FEUNJ yang berprofesi sebagai guru. 


\section{Rumusan Masalah}

Sesuai dengan uraian pada latar belakang masalah di atas, maka dapat dirumuskan masalah dalam penelitian ini adalah Apakah terdapat pengaruh langsung lingkungan belajar terhadap intensi menjadi guru?

\section{KAJIAN PUSTAKA \\ Intensi Menjadi Guru}

Intensi diartikan sebagai niat seseorang untuk melakukan suatu perilaku yang didasari oleh sikap dan norma subjektif terhadap perilaku tersebut. Norma subjektif muncul dari keyakinan normatif terhadap akibat perilaku, dan keyakinan normatif akibat perilaku terbentuk dari umpan balik yang diberikan oleh perilaku itu sendiri (Fishbein, 1975). Dalam Teori Behavior Plan (TBP) selanjutnya disampaikan definition Intentions have been defined in the TPB as: the amount of effort one is willing to exert to attain a goal (Ajzen, 1991), "behavioral plans that enable attainment of a behavioral goal" (Ajzen, 1996), or simply "proximal goals" (B andura, 1977). Definisi Intensi yang telah ditetapkan dalam Teori Perilaku Beralasan sebagai: sejumlah usaha yang dilakukan untuk mencapai tujuan (Ajzen, 2005), "rencana perilaku yang memungkinkan pencapaian tujuan "(Ajzen,1996), atau hanya "tujuan proksimal" (Bandura, 1977). Hal tersebut mengidentifikasikan bahwa perilaku seseorang yang terencana untuk mencapai suatu tujuan terlihat dari sejumlah usaha yang dilakukan.
2. Apakah terdapat pengaruh langsung sikap terhadap profesi guru terhadap intensi menjadi guru?

3. Apakah terdapat pengaruh langsung lingkungan belajar terhadap sikap terhadap profesi guru ?

Disampaikan bahwa "An expression of intention is description of something future in which the speaker is some short agent, which description he justifies ( if he does justify it) by reasions for acting, $s c$ ". Sebuah ekspresi niat adalah deskripsi sesuatu masa depan di mana pembicara beberapa agen pendek, yang deskripsi dia membenarkan (jika ia membenarkannya) oleh reasons untuk bertindak.

Guru adalah pendidik yang mengarahkan siswa dalam pembelajaran menuju suatu perubahan dalam perilaku sebagai suatu kemampuan dalam aspek kognitif, afektif dan psikomotor. Menurut Undang - undang Republik Indonesia No.14 Tahun 2005 tentang Guru dan Dosen: Guru adalah pendidik profesional dengan tugas utama mendidik, mengajar, membimbing, mengarahkan, melatih, menilai, dan mengevaluasi peserta didik pada pendidikan usia dini, pendidikan dasar, dan pendidikan menengah. Lebih lanjut disebutkan dalam pasal 8 UU RI No. 14: 2005 bahwa guru wajib memiliki kualifikasi akademik, kompetensi, sertifikat pendidik, sehat jasmani dan rohani, serta memiliki kompetensi untuk mewujudkan tujuan pendidikan nasional. 


\section{Lingkungan \\ Belajar}

Pembelajaran bersama siswa disekolah dapat terselenggara dengan baik diantaranya adalah lingkungan sekolah yang mendukung proses pembelajaran. Pembelajaran tidak selalu harus berada dalam ruangan tetapi dapat memanfaatkan pembelajaranan diluar sekolah atau lingkungan luar. Stephen E. Abbott et all (E.Abbott) menyampaikan sebagai berikut:

...Learning environment refers to the diverse physical locations, contexts, and cultures in which students learn. Since students may learn in a wide variety of settings, such as outside-ofschool locations and outdoor environments, the term is often used as a more accurate or preferred alternative to classroom, which has more limited and traditional connotations - a room with rows of desks and a chalkboard, for example.

Suryabrata (suryabrata, 2006) mengemukakan bahwa "lingkungan adalah segala sesuatu yang berada di luar individu dimana dalam keseluruhan tingkah lakunya individu tersebut berinteraksi dengan lingkungannya, baik

\section{Sikap Terhadap Profesi Guru}

Menurut W. A Gerungan menyatakan bahwa "Sikap diartikan sebagai kesediaan bereaksi individu terhadap suatu hal, suatu objek, dengan kata lain tidak ada sikap tanpa adanya objek." Hal yang sama diungkapkan oleh Robin bahwa "Sikap merupakan pernyataan evaluatif seseorang yang disadari maupun tidak disadari, langsung maupun tidak langsung”. Menurut Oemar Hamalik (Ngalim, 2004) menyampaikan bahwa lingkungan adalahsesuatu yang ada di alam sekitar yang memiliki makna atau pengaruh tertentu kepada individu. Hal tersebut sesuai dengan pendapat Ngalim ) (Ngalim, 2004)"lingkungan adalah meliputi semua kondisi-kondisi dalam dunia ini yang dalam cara - cara tertentu mempengaruhi tingkah laku kita, pertumbuhan, perkembangan atau life processes kita kecuali gen-gen dan bahkan gen-gen dapat pula dipandang sebagai menyiapkan lingkungan bagi gen yang lain”. Lingkungan itu dapat dibagi menjadi tiga bagian yaitu lingkungan alam/luar, lingkungan dalam, dan lingkungan sosial/ masyarakat. Siswa akan dapat dipengaruhi lingkungannya dalam bertindak dan membentuk suatu makna berdasarkan pembelajaran yang ia dapat. Lingkungan mempengaruhi pembelajaran dalam bentuk fisik, sosial serta budaya kepada siswa sebagai pembelajar dalam menemukan makna pembelajaran serta perilaku sebagai hasil belajar.

berkaitan dengan objek, orang, atau peristiwa". Hal tersebut menunjukkan bahwa sikap sangat dipengaruhi oleh objek yang dilanjutkan dengan suatu reaksi tertentu untuk kesediaan yang sifatnya evaluatif.

Menurut Fishbein \& Azjen, (Dalam Elis 2011) sikap merupakan 
salahsatu komponen dalam intensi terhadap perilaku tertentu. Sikap merupakan salah satu faktor yang ada dalam diri seseorang yang dipelajari untuk memberikan respon dengan cara konsisten yaitu suka atau tidak suka pada penilaian terhadap sesuaatu yang diberikan. Salahsatu pemahaman sikap yang penting adalah trilogi sikap yang terdiri dari kognitif, afektif dan konatif. Afektif berarti perasaan atau penilaian tertentu seseorang baik terhadap suatu objek orang, isu maupun kejadian. Kognitif terdiri dari pengetahuan, opini, dan kepercayaan terhadap suatu objek. Sedangkan komponen konatif merupakan perasaan atau evaluatif. Hal serupa juga disampaikan bahwa Attitude as the degree of positive or negative affect associated with some psychological object (Allen L. Edward, 1957). Sikap adalah afeksi positif atau negatif yang berhubungan dengan beberapa objek psikologis. Objek sikap dapat berupa simbol, ungkapan, slogan, orang, institusi, ideal, ide, dsb.

\section{METODE PENELITIAN}

Penelitian ini dilaksanakan di Universitas Negeri Jakarta dengan unit analisis adalah mahasiswa pendidikan pada Fakultas Ekonomi. Populasi dalam penelitian ini adalah mahasiswa Jurusan Ekonomi dan Administrasi FE UNJ yang mengambil matakuliah kependidikan pada semester VII genap tahun 2015/2016, sebanyak 398 mahasiswa pada Program studi Pendidikan ekonomi dan Administrasi yaitu: Pendidikan Akuntansi, Pendidikan Ekonomi dan Koperasi, dan Pendidikan
Berdasarkan pernyataan tersebut menunjukkan bahwa sikap seseorang terbentuk melalui pengetahuan, pemahaman dan seperangkat tindakan nyata akibat respon terhadap suatu objek atau kegiatan. Profesi guru akan dipilih berdasarkan suatu respon yang dibentuk berdasarkan aspek pengetahuan, pemahaman dan tindakan nyata yang dilakukan seseorang akibat perasaannya tentang guru sebagai suatu profesi.

Sikap mahasiswa terhadap profesi guru tercermin dalam ketiga komponen kognitif, afektif dan konatif. Komponen kognitif erat hubungannya dengan keyakinan seorang guru terhadap profesinya serta aktifitas lainnya, Komponen afektif berhubungan dengan evaluasi emosionalnya tentang senang atau tidak senangnya dalam memilih profesi dan aktifitas sebagai guru, serta komponen konatif yang berupa kesediaan mahasiswa untuk menjalankan dan tindakan nyata memilih guru sebagai profesi.

Administrasi Perkantoran serta Program Studi Pendidikan tataniaga dan jumlah sampel adalah sebanyak 186 orang.

Metode yang digunakan dalam penelitian ini adalah metode ex post facto dengan pendekatan kausal. Analisis pola hubungan antar variabel bertujuan untuk mengetahui pengaruh langsung atau tidak langsung antar variabel eksogen dan endogen dengan menggunakan model Analisis Jalur (path analysis). 


\section{HASIL PENELITIAN DAN PEMBAHASAN}

$\begin{array}{llll}\text { Pengujian normalitas pada } & \text { lingkungan belajar }\left(X_{1}\right) \text {, dan } & \text { sikap } \\ \text { penelitian ini menggunakan uji } & \text { terhadap profesi guru } & \left(X_{2}\right) \\ \text { Kolmogorov-Smirnov dengan tingkat } & \text { menggunakan program SPSS } 18 \\ \text { signifikansi 5\%. Hasil perhitungan uji } & \text { berdistribusi normoal dengan hasil } \\ \text { normalitas Kolmogorov Smirnov data } & \text { sebagai berikut: } & & \\ \text { data intensi menjadi guru (X3), } & & \end{array}$

\section{Uji Normalitas Data}

One-Sample Kolmogorov-Smirnov Test

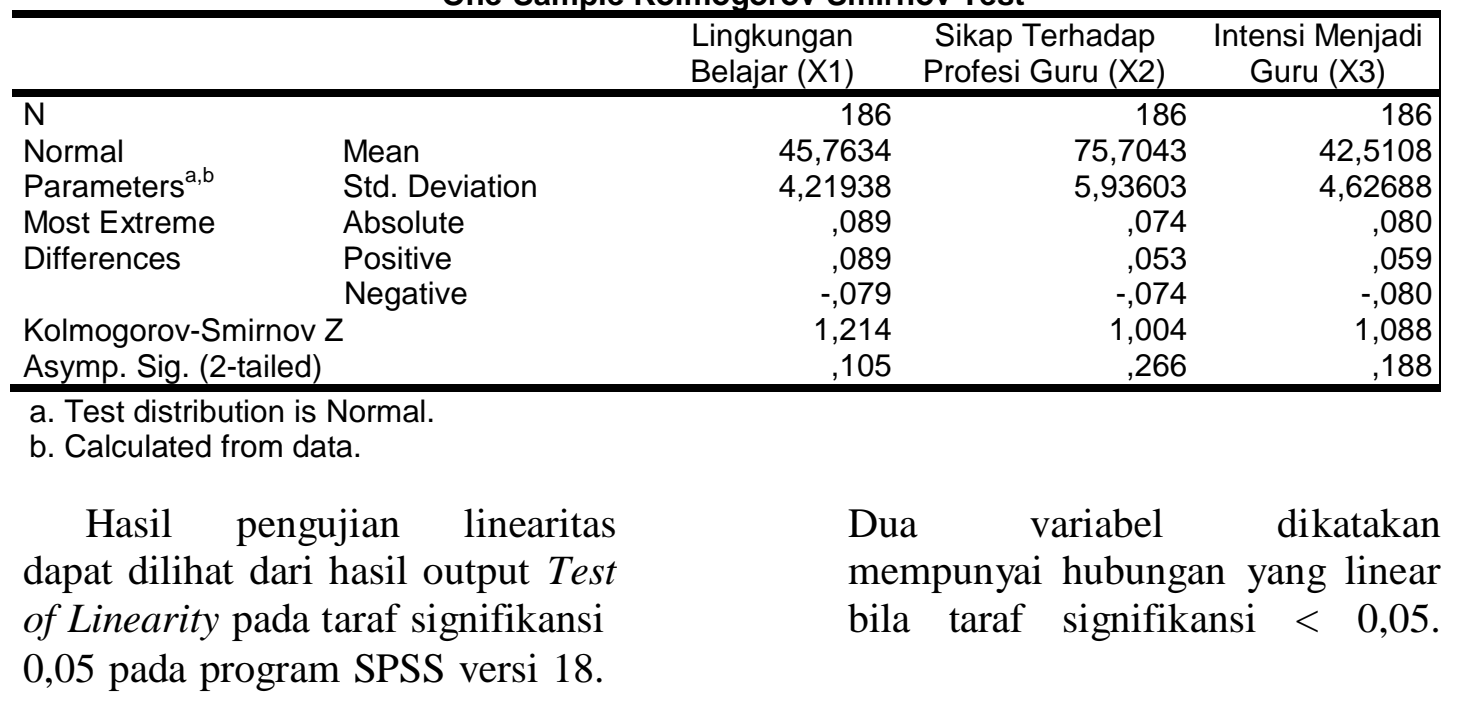

\section{Uji Linearitas $\mathrm{X}_{1}$ atas $\mathrm{X3}$}

\begin{tabular}{|c|c|c|c|c|c|c|c|}
\hline & & & $\begin{array}{l}\text { Sum of } \\
\text { Squares }\end{array}$ & df & $\begin{array}{l}\text { Mean } \\
\text { Square }\end{array}$ & $\mathrm{F}$ & Sig. \\
\hline \multirow{5}{*}{$\begin{array}{l}\text { Intensi } \\
\text { Menjadi } \\
\text { Guru (X3) * } \\
\text { Lingkungan } \\
\text { Belajar (X1) }\end{array}$} & \multirow{3}{*}{$\begin{array}{l}\text { Between } \\
\text { Groups }\end{array}$} & (Combined) & 1643,700 & 22 & 74,714 & 5,257 &, 000 \\
\hline & & Linearity & 1004,024 & 1 & 1004,024 & 70,639 & , 000 \\
\hline & & $\begin{array}{l}\text { Deviation from } \\
\text { Linearity }\end{array}$ & 639,676 & 21 & 30,461 & 2,143 & ,004 \\
\hline & \multicolumn{2}{|l|}{ Within Groups } & 2316,778 & 163 & 14,213 & & \\
\hline & \multicolumn{2}{|l|}{ Total } & 3960,478 & 185 & & & \\
\hline
\end{tabular}

Available at:

http://journal.unj.ac.id/unj/index.php/econosains/article/view/590 


\section{Uji Linearitas $\mathbf{X}_{2}$ terhadap X3}

\begin{tabular}{|c|c|c|c|c|c|c|c|}
\hline \multicolumn{8}{|c|}{ ANOVA Table } \\
\hline & & & $\begin{array}{l}\text { Sum of } \\
\text { Squares }\end{array}$ & df & $\begin{array}{l}\text { Mean } \\
\text { Square }\end{array}$ & $\mathrm{F}$ & Sig. \\
\hline \multirow{5}{*}{$\begin{array}{l}\text { Intensi } \\
\text { Menjadi } \\
\text { Guru (X3) * } \\
\text { Sikap } \\
\text { Terhadap } \\
\text { Profesi Guru } \\
\text { (X2) }\end{array}$} & \multirow{3}{*}{$\begin{array}{l}\text { Between } \\
\text { Groups }\end{array}$} & (Combined) & 2255,955 & 29 & 77,792 & 7,120 &, 000 \\
\hline & & Linearity & 1879,297 & 1 & 1879,297 & $\begin{array}{r}171,99 \\
5\end{array}$ & ,000 \\
\hline & & $\begin{array}{l}\text { Deviation from } \\
\text { Linearity }\end{array}$ & 376,658 & 28 & 13,452 & 1,231 & ,212 \\
\hline & Within Groups & & 1704,524 & 156 & 10,926 & & \\
\hline & Total & & 3960,478 & 185 & & & \\
\hline
\end{tabular}

Berdasarkan hasil pengujian diatas dapat diketahui nilai linearitas sebesar 0,000 kurang dari taraf signifikansi 0,05 . Langkah selanjutnya adalah mencari koefisien jalur yang dapat dilakukan dengan memperkalikan matriks invers koefisien korelasi antara variabel independen dengan variabel dependen. Dalam penelitian ini perhitungan koefisien jalur dilakukan dengan menggunakan SPSS.18 pada kolom standardized coefficients.

\section{Koefisien Jalur antara Variabel Independen dengan Variabel Dependen}

Coefficients $^{\mathrm{a}}$

\begin{tabular}{|c|c|c|c|c|c|c|}
\hline \multirow[t]{2}{*}{ Model } & & \multicolumn{2}{|c|}{$\begin{array}{l}\text { Unstandardized } \\
\text { Coefficients }\end{array}$} & \multirow{2}{*}{$\begin{array}{c}\begin{array}{c}\text { Standardized } \\
\text { Coefficients }\end{array} \\
\text { Beta }\end{array}$} & \multirow[b]{2}{*}{$\mathrm{t}$} & \multirow[b]{2}{*}{ Sig. } \\
\hline & & B & Std. Error & & & \\
\hline \multirow[t]{3}{*}{1} & (Constant) & $-1,933$ & 3,304 & &,- 585 & ,559 \\
\hline & $\begin{array}{l}\text { Lingkungan } \\
\text { Belajar X1 }\end{array}$ & 216, & ,067 & 398, & 3,216 & 002 \\
\hline & $\begin{array}{l}\text { Sikap Terhadap } \\
\text { Profesi Guru X2 }\end{array}$ & 457 & , 048 & -586 & 9,574 & ,000 \\
\hline
\end{tabular}

a. Dependent Variable: Intensi Menjadi Guru X3

Pengujian model secara simultan berdasarkan hasil analisis menggunakan

SPSS.18 menunjukkan bahwa model tersebut signifikan. Hal tersebut dapat dilihat dari uji $\mathrm{F}$ hitung sebesar 92,464.
Dengan nilai signifikansi $\quad 0,000$ dapat diketahui bahwa secara simultan terdapat pengaruh lingkungan belajar (X1), sikap terhadap profesi guru (X2) terhadap intensi menjadi guru (X3). 
ANOVA $^{\text {b }}$

\begin{tabular}{llrrrrr}
\hline Model & \multicolumn{5}{c}{ Sum of } & \multicolumn{2}{c}{ Mean } & \\
& & Squares & \multicolumn{1}{c}{ df } & Square & \multicolumn{1}{c}{ F } & Sig. \\
\hline 1 & Regression & 1990,619 & 2 & 995,310 & 92,464 &, $000^{\mathrm{a}}$ \\
& Residual & 1969,859 & 183 & 10,764 & & \\
& Total & 3960,478 & 185 & & & \\
\hline
\end{tabular}

b. Dependent Variable: Intensi Menjadi Guru X3

Berdasarkan data diketahui besarnya koefisien determinasi untuk model yang diteliti adalah $50,3 \% \%$. Dengan besarnya koefisien determinasi tersebut selanjutnya dapat dihitung koefisien jalur variabel lain yang

tidak diteliti dengan perhitungan berdasarkan rumus sebagai berikut:

$$
\begin{aligned}
\rho \mathbf{\rho} \varepsilon & =\sqrt{1-\mathbf{R}^{2}} \\
\rho \mathbf{\rho} \varepsilon & =\sqrt{1-0,503} \\
& =0,7049
\end{aligned}
$$

\begin{tabular}{|c|c|c|c|c|c|c|c|c|c|}
\hline \multirow[t]{2}{*}{ Model } & \multirow[b]{2}{*}{$\mathrm{R}$} & \multirow[b]{2}{*}{$\begin{array}{c}\mathrm{R} \\
\text { Square }\end{array}$} & \multirow[b]{2}{*}{$\begin{array}{l}\text { Adjusted } \\
\text { R Square }\end{array}$} & \multirow{2}{*}{$\begin{array}{l}\text { Std. } \\
\text { Error of } \\
\text { the } \\
\text { Estimate }\end{array}$} & \multicolumn{5}{|c|}{ Change Statistics } \\
\hline & & & & & $\begin{array}{c}\mathrm{R} \\
\text { Square } \\
\text { Change }\end{array}$ & $\begin{array}{c}F \\
\text { Change }\end{array}$ & df1 & df2 & $\begin{array}{c}\text { Sig. F } \\
\text { Change }\end{array}$ \\
\hline 1 &, $709^{a}$ &, 503 & ,497 & 3,28089 &, 503 & 92,464 & 2 & 183 &, 000 \\
\hline
\end{tabular}

\section{Koefisien Determinasi}

Model Summary ${ }^{b}$

a. Predictors: (Constant), Sikap Terhadap Profesi Guru X2, Lingkungan Belajar X1

b. Dependent Variable: Intensi Menjadi Guru X3

Berdasarkan perhitungan dengan menggunakan rumus diatas diperoleh koefisien jalur variabel lain (рує) sebesar 0,7049. Dengan besarnya koefisien jalur variabel lain tersebut maka pengaruh variabel lain yang tidak masuk dalam model adalah $\boldsymbol{\rho}^{2} \mathbf{y \varepsilon}=$ $(\mathbf{0 , 7 0 4 9 )})^{2}$ atau sebesar 0,496 . Dengan demikian besarnya pengaruh variabel lain yang tidak diteliti dalam model ini adalah 50\% (pembulatan).

Berdasarkan rumusan kontribusi analisis jalur diatas dapat dimasukkan besaran kontribusi variabel lingkungan belajar (X1), Sikap terhadap Profesi Guru (X2) dan Intensi menjadi Guru (X3) sebagai berikut: 


\section{Diagram Jalur Hubungan Kausal Empiris X1 dan X2 terhadap X3}

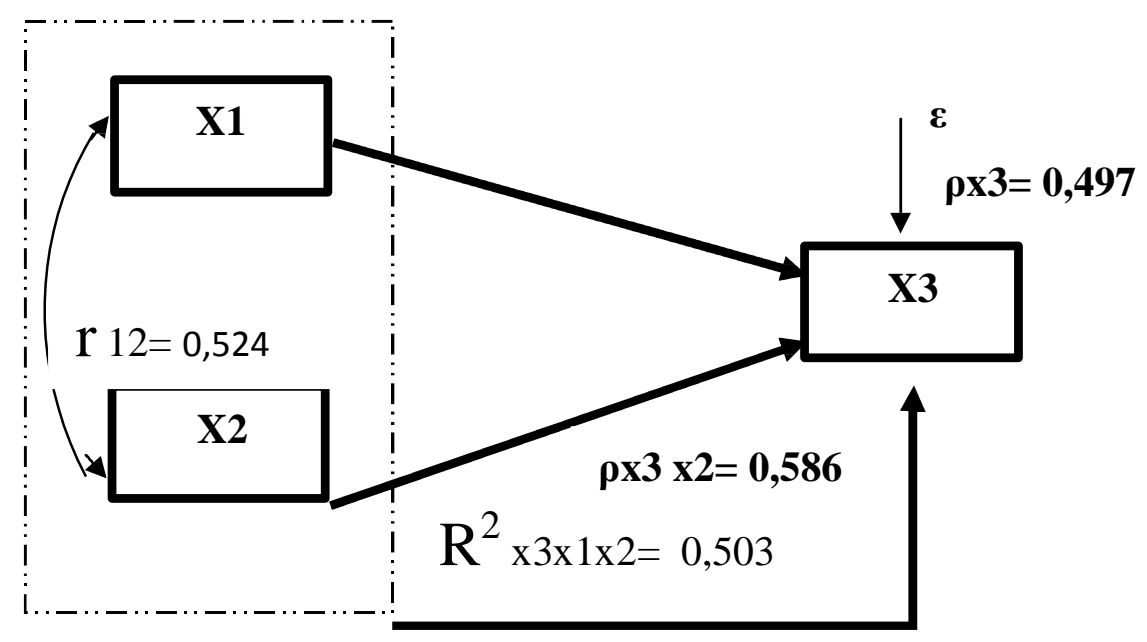

\begin{abstract}
Berdasarkan hasil perhitungan analisis jalur tersebut, maka bentuk model dapat diterima dan memberikan hasil besaran kontribusi masing masing variabel variabel lingkungan belajar (X1), sikap terhadap profesi guru (X2), dan lingkungan belajar (X3 sesuai model adalah sebagai berikut:

a. Lingkungan belajar (X1) yang secara langsung mempengaruhi intensi menjadi guru $(X 3)$ sebesar $0,398^{2}=0,158$ atau 15,8 $\%$

b. Kontribusi sikap terhadap profesi guru (X2) yang secara langsung mempengaruhi lingkungan belajar (X3) sebesar $0,586^{2}=0,3433$ atau $34,33 \%$
\end{abstract}

c. Kontribusi lingkungan belajar (X1) dan sikap terhadap profesi guru (X2) secara simultan yang langsung mempengaruhi intensi menjadi guru (X3) sebesar $\mathrm{R}^{2}=0,503=$ $50,3 \%$. Sisanya sebesar $0,497=50 \%$ dipengaruhi faktor - faktor lain yang tidak dapat dijelaskan dalam penelitian.

Berdasarkan hasil penelitian dan proses perhitungan yang telah dilakukan terhadap 186 mahasiswa Pendidikan Ekonomi Fakultas Ekonomi Universitas Negeri Jakarta mengenai pengaruh lingkungan belajar dan sikap terhadap profesi guru terhadap intensi menjadi guru, maka diperoleh perhitungan koefisien

\section{Available at:}

http://journal.unj.ac.id/unj/index.php/econosains/article/view/590 
jalur dan didapat $X 3=\mathbf{0 , 3 9 8}$ X1

$+0,586$ X2 + 0,497 $\varepsilon$.

Berdasarkan uji hipotesis yang dilakukan maka hasil analisis korelasi antara lingkungan belajar dan sikap terhadap profesi guru dengan intensi menjadi guru diperoleh besarnya kontribusi variabel sikap terhadap profesi guru ditentukan oleh variabel lingkungan belajar dan sikap terhadap profesi guru, yang dapat diketahui dari hasil $\mathrm{R}^{2} \mathrm{px} 3 \mathrm{x}_{1} \mathrm{x}_{2}$ sebesar 0,503. Secara statistik nilai ini memberikan pengertian bahwa kurang lebih 50,3\% varian intensi menjadi guru ditentukan atau dipengaruhi oleh lingkungan belajar dan sikap terhadap profesi guru, sisanya sebesar 49,7 \% ditentukan oleh faktor lain.

Berdasarkan hasil

perolehan statistik secara

individual $\mathrm{X}_{1}$ terhadap X3 diperoleh hasil Coefficients Beta sebesar 0,398. Dengan demikian variabel Lingkungan belajar $\left(X_{1}\right)$ berpengaruh langsung positif dan signifikan terhadap intensi menjadi guru (X3) sebesar 0,398 satuan. Selanjutnya berdasarkan hasil perolehan statistik secara individual $\mathrm{X}_{2}$ terhadap $\mathrm{X} 3$ diperoleh hasil Coefficients Beta sebesar 0,586. Dengan demikian variabel sikap terhadap profesi guru $\left(\mathrm{X}_{2}\right)$ berpengaruh langsung positif dan signifikan terhadap intensi menjadi guru (X3) sebesar 0,586 satuan. Untuk struktur ke 3 berdasarkan hasil perolehan statistik secara individual $\mathrm{X}_{1}$ terhadap $\mathrm{X}_{2} \quad$ diperoleh hasil Coefficients Beta sebesar 0,524. Dengan demikian variabel lingkungan belajar $\left(\mathrm{X}_{1}\right)$ berpengaruh langsung positif dan signifikan terhadap sikap terhadap profesi guru $\left(\mathrm{X}_{2}\right)$ sebesar 0,524 satuan.

Hasil penelitian ini juga membuktikan teori yang dikemukakan oleh Bandura (1977) tentang lingkungan belajar yang membentuk sikap dan perilaku seseorang untuk menentukan masa depannya, yang juga dikemukakan Azjen (2005) dalam Teori Plan Behavior bahwa Intensi seseorang dipengaruhi oleh sikap dalam membentuk perilaku yang dalam penelitian ini adalah menentukan suatu pilihan profesi sebagai seorang guru.

Hasil temuan dalam penelitian ini juga didukung oleh teori yang dikemukan oleh Winkel (2004) yang menyatakan bahwa lingkungan pendidikan sekolah bagi siswa pendidikan dasar dan menengah adalah sebuah bidang dalam kehidupan yang penuh dengan tantangan dan tuntutan terutama untuk berprestasi sebagaimana yang dihayati oleh siswa yang bermotivasi untuk menunjukan prestasi yang baik sehingga dapat diaplikasihan bagi kehidupan masa depan. 


\section{KESIMPULAN}

Berdasarkan hasil penelitian mengenai pengaruh lingkungan belajar dan sikap terhadap profesi guru terhadap intensi menjadi guru di Fakultas Ekonomi Universitas Negeri Jakarta maka dapat disimpulkan sebagai berikut :

1. Berdasarkan hasil analisis data penelitian dan proses perhitungan yang telah dilakukan terhadap 186 mahasiswa Pendidikan Ekonomi Fakultas Ekonomi Universitas Negeri Jakarta mengenai pengaruh lingkungan belajar dan sikap terhadap profesi guru terhadap intensi menjadi guru, maka diperoleh perhitungan koefisien jalur dan didapat $\mathrm{X} 3=\mathbf{0 , 3 9 8} \mathrm{X} 1$ + 0,586 X2 + 0,497 \&. Setelah dilakukan uji parsial mempunyai pengaruh yang signifikan terhadap variabel yang diuji yaitu intensi menjadi guru.

2. Lingkungan Belajar $\left(\mathrm{X}_{1}\right)$ yang diukur oleh intensi menjadi guru (X3) memiliki kontribusi yang positif dan signifikan terhadap tinggi rendahnya intensi menjadi guru. Dengan demikian tinggi rendahnya intensi menjadi guru dijelaskan oleh lingkungan belajar. Besarnya kontribusi lingkungan sbelajar secara langsung terhadap intensi menjadi guru adalah 15,8 \%. Berdasarkan hasil penelitian ini dapat disimpulkan bahwa hipotesis penelitian yang menyatakan "lingkungan belajar berpengaruh secara langsung terhadap intensi menjadi guru" dapat diterima.

3. Sikap terhadap profesi guru $\left(\mathrm{X}_{2}\right)$ yang diukur oleh intensi menjadi guru (X3) memiliki kontribusi yang positif dan signifikan terhadap tinggi rendahnya intensi menjadi guru. Dengan demikian tinggi rendahnya intensi menjadi guru dijelaskan oleh sikap terhadap profesi guru. Besarnya kontribusi sikap terhadap profesi guru secara langsung terhadap hasil belajar ekonomi adalah 34,33 \%. Berdasarkan hasil penelitian ini dapat disimpulkan bahwa hipotesis penelitian yang menyatakan "Sikap terhadap profesi guru berpengaruh secara langsung terhadap intensi menjadi guru" dapat diterima.

4. Lingkungan belajarh $\left(X_{1}\right)$ yang diukur oleh sikap terhadap profesi guru $\left(\mathrm{X}_{2}\right)$ memiliki kontribusi yang positif dan signifikan terhadap tinggi rendahnya intensi menjadi guru. Dengan demikian tinggi rendahnya sikap terhadap profesi guru dijelaskan oleh lingkungan belajar. Besarnya 
kontribusi lingkungan belajar secara langsung terhadap sikap terhadap profesi guru adalah 50,3 \%. Berdasarkan hasil penelitian ini dapat disimpulkan bahwa hipotesis penelitian yang

\section{SARAN}

Berdasarkan hasil penelitian yang telah diuraikan di atas, maka peneliti memberikan beberapa saran yang diharapkan dapat menjadi masukan yang bermanfaat, antara lain:

1. Bagi Fakultas Ekonomi Universitas Negeri Jakarta

a) Menciptakan lingkungan belajar yang lebih efektif, kondusif, dan lebih nyaman untuk pembelajaran

b) Melengkapi dan memperbaiki sarana dan prasarana pembelajaran agar nyaman digunakan untuk belajar.

2. Bagi Dosen Kependidikan Ekonomi

a) Memberikan pemahaman yang baik terhadap kompetensi kependidikan sebagai calon pendidik sebagai profesi.

b) Memberikan proses pembelajaran yang baik menyatakan "lingkungan belajar dan sikap terhadap profesi guru berpengaruh secara langsung terhadap intensi menjadi guru" dapat diterima. dalam membentuk sikap mahasiswa terhadap profesi guru.

c) Menjaga kondusifitas lingkungan pembelajaran yang mendukung berkembangnya potensi mahasiswa sebagai calon pendidik.

3. Bagi mahasiswa

a) Memanfatkan semua fasilitas dan sarana prasarana yang disediakan oleh kampus dengan baik.

b) Meningkatkan kompetensi dan pemahaman terhadap profesi guru dalam membentuk sikap yang baik.

c) Meningkatkan kompetensi mata kuliah kependidikan dan etika profesi guru. 


\section{DAFTAR PUSTAKA}

Ajzen, I. (2005). Attitudes, Personality, and Behavior. McGraw-Hill Education.

Ama Khayam, K. (. (2013). Guru Honor Di Upah Rp. 50.000 per bulan. Jakarta: http://edukasi.kompas.com/rea d/2013/05/28/14234136/Guru. Honor.Diupah/Rp.50.000.Per.Bu lan.

Bandura, A. (1977). Social Learning Theory. Englewood Chliffs: Prentice Hall.

E.Abbott, S. (n.d.). Learning Environment. http://edglossary.org/learningenvironment.

Fauzi, A. d. (2014). Tracer Study Fakultas Ekonomi Universitas Negeri Jakarta. Jakarta: FE UNJ.

Fishbein, M. d. (1975). Belief, Attitude, Intention, and Behavior: An Introduction to Theory and Research. London: Addison Wesley Publishing Company.

Gabrillin, A. (2014). Anies Baswedan Sebut Pendidikan Indonesia Gawat Darurat. Indonesia: http://edukasi.kompas.com/rea d/2014/12/01/13455441/anies. baswedan.sebut.pendidikan.indo nesia.gawat.darurat.

Ngalim, P. (2004). Psikologi Pendidikan. Bandung: PT. Remaja Rosda Karya.

Setiyadi, B. (2014). Gaji Terendah PNS DKI Rp. 12 Juta. Jakarta: http://www.koran-sindo.com.

suryabrata, S. (2006). Psikologi Pendidikan. Jakarta: http://news.okezone.com/read/2 015/06/29/65/1172998/kemenris tek-wajibkan-cpns-gurumengajar-di-pedalaman. 